\title{
PENGARUH MODEL PEMBELAJARAN CHILDRENS LEARNING IN SCIENCE (CLIS) BERBANTUAN MEDIA LINGKUNGAN TERHADAP KOMPETENSI PENGETAHUAN IPA
}

\author{
Ni Ketut Arisantiani \\ Jurusan Pendidikan Guru Sekolah Dasar Universitas Pendidikan Ganesha \\ E-mail:arisantiani@gmail.com \\ Made Putra \\ Jurusan Pendidikan Guru Sekolah Dasar Universitas Pendidikan Ganesha \\ E-mail: putramd13@yahoo.com \\ Ni Nyoman Ganing \\ Jurusan Pendidikan Guru Sekolah Dasar Universitas Pendidikan Ganesha \\ E-mail: nyomanganing@yahoo.co.id
}

\begin{abstract}
Abstrak
Permasalahan dalam penelitian ini adalah kurang optimalnya kompetensi pengetahuan IPA siswa kelas IV. Penelitian ini bertujuan untuk mengetahui perbedaan yang signifikan kompetensi pengetahuan IPA antara kelompok siswa yang dibelajarkan menggunakan model pembelajaran Childrens Learning In Science (CLIS) berbantuan media lingkungan dengan kelompok siswa yang dibelajarkan menggunakan pembelajaran konvensional pada siswa kelas IV SD Gugus Yos Sudarso Kecamatan Denpasar Selatan tahun pelajaran 2016/2017. Penelitian ini adalah penelitian eksperimen semu (quasy experimental design) dengan rancangan yang digunakan adalah "rancangan kelompok non-ekuivalen". Populasi dalam penelitian ini adalah semua siswa kelas IV SD Gugus Yos Sudarso. Sampel diambil dengan teknik random sampling. Data yang dikumpulkan adalah kompetensi pengetahuan IPA dengan menggunakan tes kompetensi pengetahuan IPA bentuk pilihan ganda biasa yang kemudian dianalisis dengan uji-t. Berdasarkan hasil analisis diperoleh rata-rata nilai kelompok eksperimen yaitu 76,02 berada pada kategori baik dan kelompok kontrol yaitu 69,43 berada pada kategori cukup. Berdasarkan hasil uji-t diperoleh thitung $=3,71$ dan pada taraf signifikansi $5 \%$ dengan $\mathrm{dk}=90$ didapat tabel $=1,98$. Kriteria pengujian thitung $>\mathrm{t}_{\text {tabel }}(3,71>1,98)$ maka $\mathrm{H}_{0}$ ditolak. Hasil penelitian menunjukkan bahwa terdapat perbedaan signifikan kompetensi pengetahuan IPA antara kelompok siswa yang dibelajarkan menggunakan model pembelajaran CLIS berbantuan media lingkungan dengan kelompok siswa yang dibelajarkan menggunakan pembelajaran konvensional pada kelas IV SD Gugus Yos Sudarso Kecamatan Denpasar Selatan. Dapat disimpulkan bahwa penerapan model pembelajaran CLIS berbantuan media lingkungan berpengaruh terhadap kompetensi pengetahuan IPA pada siswa kelas IV SD Gugus Yos Sudarso Kecamatan Denpasar Selatan tahun pelajaran 2016/2017.
\end{abstract}

Kata kunci: model pembelajaran CLIS, media lingkungan, kompetensi pengetahuan IPA

\begin{abstract}
Problem in this research was students less optimal competence of science knowledge students in fourth grade. This research was purposed to determine significant differences in competence of science knowledge between groups of students who learned use CLIS learning model of media assisted learning enviroment and a group of students that learned use conventional learning at elementary fourth grade students clusters Yos Sudarso South Denpasar district academic year 2016/2017. This research type was a quasy experimental which used untreated control group design with pretest and posttest. The population in this research were all elementary fourth grade students clusters Yos Sudarso. Samples were taken by random sampling technique. The data collected is competence of science knowledge fourth grade using competence of science knowledge test usual multiple choice and then analyzed by t-test. Based on the results obtained by analysis of the average value of experimental group is 76,02 in the category good and control group is 69,43 in the category enough. Based on the t-test results obtained by $t_{\text {count }}=3,71$ and at the $5 \%$ significance level by dk $=90$ obtained $t_{\text {table }}=1,98$. By testing criteria $t_{\text {count }}>t_{\text {table }}(3,71>1,98)$ then $\mathrm{H}_{0}$ is rejected. This means that there is significant difference in competence of science knowledge between groups of students who learned use CLIS learning model of media assisted learning enviroment and a group of students that learned use conventional learning at elementary fourth grade students clusters Yos Sudarso South Denpasar district. It can be concluded that the application of the CLIS learning model of media assisted learning enviroment has effect on competence of science knowledge students elementary fourth grade clusters Yos Sudarso South Denpasar district academic year 2016/2017.
\end{abstract}

Keywords : CLIS learning model, media assisted learning enviroment, competence of science knowledge 


\section{Pendahuluan}

Kurikulum dalam sejarah pendidikan di Indonesia sudah beberapa kali diadakan perubahan dan perbaikan. Banyak persepsi tentang pemahaman kurikulum karena itu terdapat berbagai macam pengertian atau pemahaman sekitar kurikulum. Kurikulum adalah, "seperangkat rencana dan pengaturan mengenai sisi dan bahan pelajaran serta cara yang digunakan sebagai pedoman penyelenggaraan kegiatan belajar mengajar" (Sagala, 2013: 234). Kurikulum tidak bersifat stagnan namun kurikulum bersifat dinamis karena, kurikulum itu sendiri terkait erat dengan perubahan dan perkembangan yang terjadi dalam kehidupan masyarakat, berbangsa, bernegara, serta tidak terlepas dari pengaruh global, perkembangan ilmu pengetahuan dan teknologi serta seni dan budaya (Kurniasih dan Berlin, 2014: 3).

Saat ini di Indonesia kurikulum yang sedang dikembangkan yakni Kurikulum 2013. Dampak dari pengembangan kurikulum 2013 yakni siswa menjadi lebih aktif dan menggali lebih banyak sendiri informasi di dalam pembelajaran di lingkungan sekolah maupun di luar sekolah. Perubahan pola pikir Kurikulum 2013 mengakibatkan pendekatan pembelajaran yang digunakan juga berubah. Pendekatan pembelajaran yang digunakan adalah pendekatan saintifik atau pendekatan ilmiah. Menurut Sinambela (2013), terdapat 5 langkahlangkah pembelajaran yang digunakan dalam pendekatan saintifik. Model pembelajaran yang terdapat di dalam pengembangan Kurikulum 2013 adalah model yang menganut pandangan konstruktivisme. Kegiatan siswa lebih cenderung untuk mencari tahu tentang prinsip dan konsep ilmu pengetahuan tersebut bukan menunggu diberikan oleh guru. Pada Kurikulum 2013 terdapat model yang menjadi pendukung yang sesuai dengan prinsip Kurikulum 2013. Sani (2014: 76) mengemukakan bahwa model yang sesuai dengan pembelajaran saintifik antara lain (1) pembelajaran berbasis inkuiri, (2) pembelajaran penemuan, (3) pembelajaran berbasis masalah, dan (4) pembelajaran berbasis proyek. Keempat model tersebut bukan model yang harus dilaksanakan dalam pembelajaran yang mengimplementasikan Kurikulum 2013 karena masih bisa menggunakan model pembelajaran lain yang sesuai dengan pandangan konstruktivisme.

Selain keempat model tersebut masih ada model pembelajaran yang menganut pandangan konstruktivisme yang sesuai dengan pedoman Kurikulum 2013. Model pembelajaran yang ditawarkan untuk permasalahan ini adalah model pembelajaran Children's Learning In Science (CLIS) sebagai inovasi pembelajaran. Model CLIS merupakan, "model pembelajaran yang berusaha mengembangkan idea atau gagasan siswa tentang suatu masalah tertentu dalam pembelajaran serta merekonstruksi ide atau gagasan berdasarkan hasil pengamatan atau percobaan" (Rahayu, 2015: 147). Samatowa (2016: 74) menyatakan bahwa, model pembelajaran CLIS termasuk dalam model yang menganut pandangan konstruktivisme.

CLIS juga dikatakan sebagai sebuah model pembelajaran karena memiliki langkah-langkah (sintaks) yang digunakan oleh guru sebagai pedoman dalam merancang dan melaksanakan pembelajaran dikelas. Seperti yang diungkapkan oleh Wisudawati dan Eka (2014: 49) model pembelajaran merupakan, "kerangka konseptual yang melukiskan prosedur secara sistematis dalam mengorganisasikan pengalaman belajar untuk mencapai tujuan pembelajaran".

Rahayu (2015: 147) menyatakan bahwa, tujuan dari model pembelajaran CLIS untuk mengungkapkan berbagai gagasan tentang topik yang dibahas dalam pembelajaran, mengungkapkan gagasan serta membandingkan gagasan dengan gagasan siswa lainnya dan mendiskusikannya untuk menyamakan persepsi. Pembelajaran dengan Model CLIS lebih menekankan pada penyempurnaan dalam mendapatkan ide dan menyesuaikan dengan ilmu pengetahuan yang ada yang selanjutkan dikemukakan dengan pendapat sendiri. Model pembelajaran CLIS memiliki karakteristik yaitu, (1) dilandasi oleh pandangan konstruktivisme karena membantu membangun pemikiran siswa, (2) pembelajaran berpusat pada siswa, (3) melakukan aktivitas hands on/ mind on, dan (4) menggunakan lingkungan sebagai sumber belajar (Budiarti : 2014).

Model pembelajaran Children Learning In Science (CLIS) terdiri dari lima langkah yaitu (1) orientasi, (2) pemunculan gagasan, (3) penyusunan ulang gagasan, (4) penerapan gagasan, dan (5) pemantapan gagasan. Langkah - langkah dalam model pembelajaran CLIS secara tidak disadari akan membantu siswa mengubah konsepsi awal siswa yang salah menuju konsepsi yang benar dengan melewati pembelajaran yang menarik dan bermakna.

Keunggulan dari model pembelajaran CLIS antara lain (1) adanya interaksi yang baik antar siswa karena terbentuknya kerjasama dalam mengkonstruksi gagasan, (2) siswa terlibat langsung dalam pembelajaran (3) suasana pembelajaran menjadi lebih aktif, kreatif, dan menyenangkan, (4) guru mengajar dengan efektif sehingga pembelajaran menjadi lebih bermakna.

Salah satu cara menerapkan model pembelajaran yang inovatif yaitu dengan memanfaatkan alam sekitar dalam belajar, melibatkan siswa secara langsung dalam pembelajaran di dalam kelas maupun di luar kelas serta membimbing siswa menemukan dan merekonstruksi pengetahuannya sendiri. Lingkungan merupakan sumber belajar yang paling efektif dan efisien serta tidak membutuhkan banyak biaya yang besar dalam meningkatkan motivasi belajar siswa (Uno dan Nurdin, 2012: 137). Sehingga lingkungan cocok digunakan sebagai sumber dan media pembelajaran. Emda (2011) menyatakan bahwa, media pembelajaran adalah semua saluran pesan yang dapat digunakan sebagai sarana komunikasi dalam proses belajar mengajar. Secara umum media 
pembelajaran dibagi dua yaitu media yang dirancang secara khusus untuk pembelajaran dan media yang tidak dirancang untuk belajar tetapi dapat dimanfaatkan untuk proses pembelajaran. Salah satu media pembelajaran yang tidak dirancang itu adalah lingkungan.

Sebelum menggunakan lingkungan sebagai media pembelajaran, ada baiknya memperhatikan beberapa aspek yang dapat mensukseskan proses pembelajaran. Setiawan, dkk (2009) menyebutkan bahwa, sebelum memilih lingkungan sebagai media belajar, maka perlu memperhatikan beberapa hal diantaranya (1) lingkungan yang dipilih adalah lingkungan yang tidak membahayakan kesehatan jiwa siswa, (2) memperhatikan keamanan lingkungan yang akan digunakan sebagai media pembelajaran, (3) pemilihan lingkungan perlu disesuaikan dengan tingkat pendidikan dan usia siswa, (4) pemilihan lingkungan bukanlah berdasarkan pilihan atau kesukaan guru tetapi berdasarkan tujuan pembelajaran dan karakteristik siswa. (5) mencari alternatif lain apabila lingkungan yang diperlukan membutuhkan biaya yang mahal.

Lingkungan untuk pendidikan perlu dirancang dan dikembangkan agar secara nyata menumbuhkan daya cipta siswa serta mampu merealisasikan gagasan dengan situasi yang baru. Menurut Kosasih (2014), lingkungan sebagai media pembelajaran dapat dibedakan antara lain (1) lingkungan alam, (2) lingkungan sosial dan (3) lingkungan budaya. Lingkungan alam, sosial dan budaya di sekitar sekolah merupakan sumber daya yang sangat kaya untuk bahan belajar siswa. Salah satu pemanfaatan lingkungan di sekolah dengan pengaturan lingkungan kelas yang dapat menumbuhkan semangat dan motivasi siswa. Pengaturan kelas yang baik akan memudahkan mewujudkan tujuan pembelajaran, misalnya bisa dirancang semenarik mungkin dengan gambar, warna dan tulisan-tulisan yang memenuhi rasa etika dan konsep yang jelas. Selain penggunaan media lingkungan kelas, belajar di luar kelas dan memanfaatkan lingkungan sekitar akan mampu menggugah semangat belajar siswa dan menunjang tercapainya tujuan pembelajaran yang maksimal. Samatowa (2016: 103) menyatakan bahwa, lingkungan sekolah sebagai laboratorium alam dapat didesain sebagai taman hias dengan cara guru mengidentifikasi kebun/ taman sekolah yang berpotensi sebagai sarana belajar.

Erviana (2015) menyebutkan bahwa, memanfaatkan lingkungan sebagai media pembelajaran memiliki beberapa keunggulan antara lain (1) menghemat biaya, (2) memberikan pengalaman yang nyata kepada siswa, (3) karena benda-benda tersebut berasal dari lingkungan siswa, maka benda-benda tersebut akan sesuai dengan karakteristik dan kebutuhan siswa, (4) pelajaran lebih aplikatif, (5) memberikan pengalaman langsung kepada siswa, (6) lebih komunikatif.

Model pembelajaran CLIS yang dikembangkan melalui bantuan media lingkungan akan mampu membawa pembaruan dalam pembelajaran. Adapun langkah-langkah pembelajarannya tetap mengikuti langkah model pembelajaran CLIS namun pada fase tertentu menggunakan media lingkungan. Langkahlangkahnya adalah (1) Pada langkah orientasi, guru memusatkan perhatian siswa dengan dengan cara mengajak siswa melihat fenomena yang terjadi pada kehidupan sehari-hari, yang berkaitan dengan topik yang dipelajari dengan menggunakan lingkungan sebagai media pembelajaran sedangkan siswa melakukan pengamatan terhadap fenomena yang ada dengan bantuan pemanfaatan lingkungan sekolah. (2) Pada langkah pemunculan gagasan, guru mengeksplorasi pengetahuan siswa sedangkan siswa dihadapkan dengan permasalahan yang mengandung teka-teki untuk memunculkan konsepsi awal siswa. (3) Pada langkah penyusunan ulang gagasan, terdapat 3 tahap diantaranya (a) pada langkah pengungkapan dan pertukaran gagasan, guru tidak membenarkan serta menyalahkan jawaban siswa sedangkan siswa membentuk kelompok kecil, kemudian di dalam kelompok siswa mengungkapkan dan mendiskusikan gagasan pada langkah kedua. Salah satu anggota kelompok melaporkan hasil diskusi, (b) pada langkah situasi konflik, guru mengarahkan siswa mencari informasi terkait materi sedangkan siswa diberi kesempatan untuk mencari pengertian ilmiah yang sedang dipelajari di dalam buku teks kemudian mencari perbedaan antara konsepsi awal dengan konsep ilmiah yang ada di buku, (c) pada langkah konstruksi gagasan baru dan evaluasi, guru membimbing siswa dalam mengkonstruksi gagasan baru sedangkan siswa diberikan kesempatan untuk melakukan observasi dengan memanfaatkan kembali lingkungan lalu mendiskusikannya. (4) Pada langkah penerapan gagasan, guru memeriksa jawaban siswa yang belum konsisten dengan jawaban ilmiah sedangkan siswa diminta menjawab pertanyaan yang disusun untuk menerapkan konsep ilmiah yang telah dikembangkan siswa melalui percobaan atau observasi ke dalam situasi baru. (5) Pada langkah pemantapan gagasan, guru mengarahkan siswa untuk menyampaikan simpulan informasi yang diperoleh sedangkan siswa mengemukakan argumentasi dan gagasan barunya melalui penguatan dengan konsep ilmiah.

Pembelajaran Kurikulum 2013 yang sudah mengusung pendekatan sainfitik sangat cocok dipadukan dengan model pembelajaran CLIS karena adanya kesamaan pandangan konstruktivisme. Bahan pelajaran pada Kurikulum 2013 dibelajarkan secara tematik yang disempurnakan dan disederhanakan dari kurikulum KTSP. Salah satu muatan mata pelajaran pada struktur kurikulum di SD adalah mata pelajaran IPA. IPA merupakan, "rumpun ilmu, memiliki karakteristik khusus yaitu mempelajari fenomena alam yang faktual, baik berupa kenyataan atau kejadian dan hubungan sebab akibatnya" (Wisudawati dan Eka, 2014: 22). IPA menitik beratkan pada suatu proses penelitian. Samatowa (2016) menyatakan bahwa, alasan IPA perlu dilaksanakan pada kurikulum sekolah karena 1) IPA berfaedah bagi suatu bangsa sebab IPA sebagai dasar teknologi, 2) IPA 
merupakan mata pelajaran yang melatih kemampuan berpikir kritis bila diajarkan menurut cara yang tepat, 3) bila diajarkan melalui pecobaan, IPA bukanlah mata pelajaran yang bersifat hafalan belaka, dan 4) mata pelajaran IPA mempunyai nilai-nilai pendidikan yang dapat membentuk kepribadian siswa secara keseluruhan.

Begitu pentingnya muatan mata pelajaran IPA yang seharusnya menyenangkan dan digemari oleh siswa namun kenyataannya IPA dianggap sulit. Permasalahan yang terjadi di sekolah, IPA tidak dipahami seutuhnya oleh siswa karena bentuk materi yang banyak menghafal. Berdasarkan hasil wawancara dengan guru kelas IV di lingkungan Gugus Yos Sudarso menyatakan bahwa perolehan nilai akhir kompetensi pengetahuan siswa kurang optimal. Ini dapat dilihat dengan perolehan nilai akhir kompetensi pengetahuan IPA pada tema sebelumnya secara klasikal masih berada di bawah Kriteria Ketuntasan Minimal (KKM). Nilai akhir kompetensi IPA siswa dikatakan tuntas apabila memenuhi KKM sekitar 68,00. Hasil wawancara tersebut sesuai dengan pendapat yang dikemukakan oleh Susanto (2013: 165) menyatakan bahwa, anggapan tentang IPA sulit oleh peserta didik terbukti benar terlihat dari hasil perolehan Ujian Akhir Sekolah (UAS) yang dilaporkan Depdiknas masih sangat jauh dari standar yang diharapkan. Wisudawati \& Eka (2014: 31) menyatakan bahwa, proses belajar IPA harusnya ditandai dengan adanya perubahan pada individu yang belajar, baik berupa sikap dan perilaku, pengetahuan, pola pikir dan konsep nilai yang dianut sehingga tujuan pembelajaran bisa tercapai. Hal lain yang menjadi permasalahan juga yaitu kurangnya inovasi di dalam pembelajaran yang mengakibatkan masih kurangnya penguasaan kompetensi pengetahuan IPA siswa. Adanya perbaikan proses pembelajaran di kelas yang dikondisikan dengan situasi dan kondisi sekolah masing-masing diharapkan menjadi salah satu upaya penyempurnaan Kurikulum 2013.

Kesenjangan antara kenyataan yang terjadi di lapangan dengan kondisi ideal yang diharapkan tentunya berdampak pada kompetensi pada aspek pengetahuan (kognitif). Dalam UU No. 20 Tahun 2013 tentang Sistem Pendidikan didefinisikan pula bahwa kompetensi adalah kualifikasi kemampuan lulusan yang mencakup sikap, pengetahuan, dan keterampilan yang akan menjadi acuan bagi pengembangan kurikulum dalam rangka mewujudkan tujuan pendidikan nasional. Pencapaian pada kompetensi pengetahuan akan mewujudkan salah satu tujuan pendidikan nasional.

Berbagai permasalahan yang ditemukan dalam pelaksanaan pembelajaran dikelas, baik permasalahan siswa, permasalahan metodelogis, permasalahan akademis maupun non akademis lainnya, semuanya tentu berimplikasi langsung dan tidak langsung terhadap pencapaian hasil pembelajaran. Oleh karena itu mengkombinasikan pendekatan saintifik sebagai bawaan dari kurikulum 2013 yang dipadukan dengan model pembelajaran CLIS berbantuan media lingkungan dalam pembelajaran dapat menciptakan suasana pembelajaran yang menarik, siswa lebih aktif, dan menumbuhkan rasa ingin tahu yang besar, dengan demikian hasil belajar pengetahuan IPA siswa dapat lebih optimal.

Berdasarkan paparan tersebut, tujuan dalam penelitian ini adalah untuk mengetahui perbedaan yang signifikan kompetensi pengetahuan IPA antara kelompok siswa yang dibelajarkan menggunakan model pembelajaran CLIS berbantuan media lingkungan dengan kelompok siswa yang dibelajarkan menggunakan pembelajaran konvensional pada siswa kelas IV SD Gugus Yos Sudarso Kecamatan Denpasar Selatan.

\section{Metode Penelitian}

Rancangan penelitian ini adalah eksperimen semu (quasi eksperimental design). Rancangan eksperimen semu yang digunakan dalam penelitian ini adalah rancangan kelompok non-ekuivalen. Dalam rancangan ini, ada dua kelompok subjek. Satu mendapat perlakuan sebagai kelompok eksperimen dan satu kelompok sebagai kelompok kontrol. Pada rancangan penelitian ini hanya memperhitungkan skor post-test saja yang dilakukan pada akhir penelitian atau tanpa memperhitungkan skor pre-test. Hal tersebut didukung oleh pendapat Dantes (2012: 97) yang menyatakan bahwa, pre-test biasanya digunakan untuk mengukur ekuivalensi atau penyetaraan kelompok.

Populasi adalah keseluruhan objek dalam penelitian yang merujuk pada keseluruhan kelompok dari sampel yang diambil untuk dipelajari dan kemudian ditarik kesimpulannya. Populasi pada penelitian ini adalah seluruh siswa SD Gugus Gugus Yos Sudarso, Kecamatan Denpasar Selatan, yang terdiri dari 8 kelas dalam 5 sekolah. Jumlah populasi dari penelitian ini adalah 311 siswa.

Pengambilan sampel dari populasi menggunakan teknik sampling. Teknik sampling yang digunakan pada penelitian ini adalah menggunakan sampel acak atau random sampling. Random sampling adalah salah satu cara pengambilan sampel yang representatif. Pengambilan sampel secara acak berarti pengambilan sampel yang memungkinkan setiap individu dalam populasi mempunyai peluang yang sama untuk dijadikan sampel (Sukmadinata, 2012: 253). Sebelum melakukan random sampling terlebih dahulu melakukan penyetaraan dengan memberikan pre-test ke-8 kelas yang ada di gugus Yos Sudarso lalu melakukan random dan terpilih 2 sekolah yaitu kelas IV SDN 5 Sanur sebagai kelompok eksperimen dan kelas IV SDN 6 Sanur sebagai kelompok kontrol.

Dalam penelitian ini terdapat kontrol validitas internal dan validitas ekternal. Faktor yang menjadi ancaman di validitas internal dalam penelitian ini adalah faktor pengujian sebelumnya/pretesting. Pengujian 
sebelumnya mengacu pada dampak atau pengaruh suatu tes sebelumnya atau pretest, sebelum dilakukan posttest setelah subjek diberikan perlakuan. Dampak pelaksanaan pretest mungkin saja akan meningkatkan kemungkinan bahwa individu atau subjek akan mengerjakan tes lebih baik pada posttest, terutama jika pretest yang diberikan sama atau identik dengan posttest yang diberikan. Untuk menghindari hal tersebut terjadi dan memengaruhi hasil penelitian, maka dapat dilakukan penataan pada tes yang digunakan. Pada penelitian ini pretest diberikan bertujuan untuk menyetarakan kelompok siswa. Jadi perumusan soal pretest yang digunakan mengacu pada indikator di tema sebelum perlakuan diberikan. Kemudian untuk soal posttest mengacu pada indikator di tema sesuai dengan perlakuan. Sedangkan beberapa ancaman yang berkaitan dengan validitas eskternal yaitu (1) efek seleksi terhadap sampel, dengan cara mengatasinya yaitu dengan melakukan penyetaraan terlebih dahulu sebelum melakukan random agar pengambilan sampel representatif. (2) efek prosedur eksperimen, dengan cara mengatasinya yaitu Pemberian perlakuan dilakukan oleh guru kelas yang bersangkutan agar siswa tidak menyadari bahwa mereka sedang diteliti. Peneliti dalam pelaksanaan perlakuan hanya menyediakan sarana dan prasarana yang digunakan dalam pembelajaran serta mensosialisasikan kepada guru kelas yang bersangkutan mengenai model pembelajaran yang digunakan dalam penelitian.

Data yang dikumpulkan meliputi data kompetensi pengetahuan IPA pada tema tempat tinggalku. Teknik pengumpulan data mengunakan metode tes dengan instrumen penelitian berupa tes hasil belajar objektif dalam bentuk pilihan ganda biasa dengan empat pilihan (multiple choice item test). Untuk skala pengukuran yang digunakan yaitu penskoran dengan skor nol untuk siswa yang menjawab salah dan skor 1 untuk siswa yang menjawab benar pada setiap item butir soal. Instrumen penelitian sebelum diujikan, dilakukan validasi pakar terlebih dahulu kemudian dilakukan uji coba sebanyak 50 butir soal. Setelah uji coba soal tersebut akan dianalisis validitas, reliabilitas, tingkat kesukaran dan daya bedanya. Banyak butir soal yang memenuhi syarat pada uji coba tersebut sebanyak 34 butir soal.

Teknik analisis data yang digunakan dalam penelitian ini adalah teknik analisis statistik deskriptif dan statistik inferensial. Teknik analisis deskriptif berupa penghitungan mean, standar deviasi dan varians. Hasil analisis deskriptif kemudian disajikan dalam histogram dan dilihat pencapaiannya dengan mengkategorikan pada PAP skala lima. Teknik statistik inferensial didahului dengan uji prasyarat yang berupa uji normalitas dan uji homogenitas. Data dapat dianalisis dengan statistik inferensial setelah data tersebut melewati uji prasyarat dan dinyatakan berdistribusi normal serta homogen. pada statistik inferensial, untuk menguji hipotesis digunakan beda mean (uji-t) dengan rumus polled varians.

\section{Hasil dan Pembahasan \\ Hasil Penelitian}

Data yang dikumpulkan dalam penelitian pada kelas IV SDN 5 Sanur sebagai kelompok eksperimen yaitu nilai akhir kompetensi pengetahuan IPA yang dibelajarkan menggunakan model pembelajaran CLIS berbantuan media lingkungan memiliki rata-rata 76,02; standar deviasi 7,8995; varian 63,31; nilai minimum 62 dan nilai maksimum 94. Sedangkan data pada kelas IV SDN 6 Sanur sebagai kelompok kontrol yaitu nilai akhir kompetensi pengetahuan IPA yang dibelajarkan menggunakan pembelajaran konvensional memiliki rata-rata 69,43; standar deviasi 10,06; varian 101,20; nilai minimum 50 dan nilai maksimum 85. Frekuensi nilai akhir kompetensi pengetahuan IPA siswa kelompok eksperimen dapat dilihat pada histogram berikut.

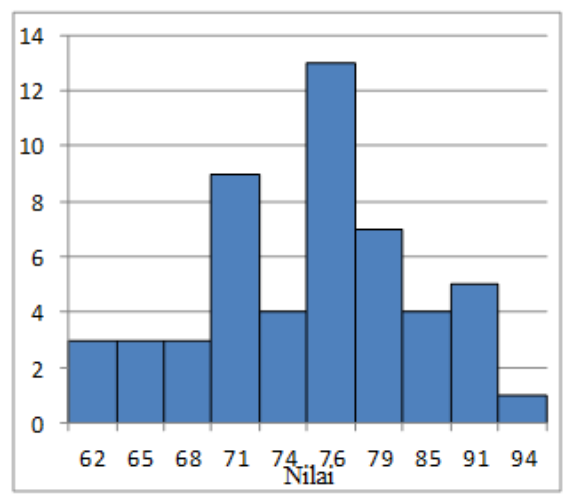

Gambar 1. Grafik Nilai Akhir Kompetensi Pengetahuan IPA Kelompok Eksperimen

Sedangkan histogram nilai akhir kompetensi pengetahuan IPA siswa kelompok kontrol dapat dilihat sebagai berikut. 


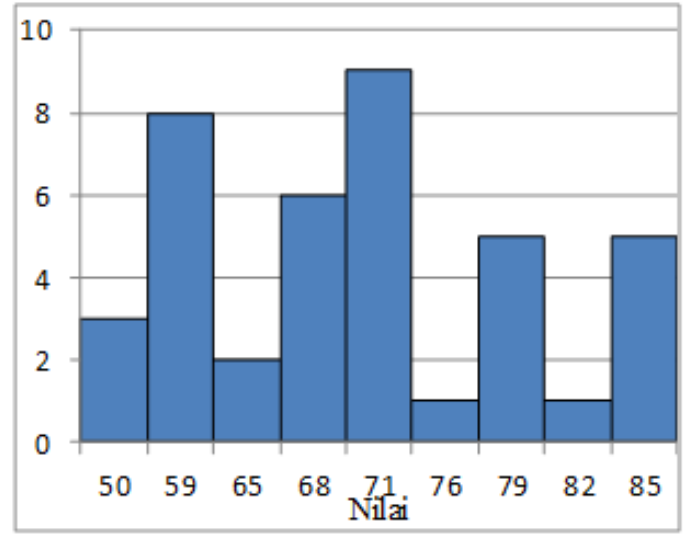

Gambar 2. Grafik Nilai Akhir Kompetensi Pengetahuan IPA Kelompok Kontrol

Sebelum dilakukan pengujian hipotesis terlebih dahulu dilakukan uji prasyarat yang meliputi uji normalitas dan uji homogenitas.

Uji normalitas dilakukan untuk mengetahui sebaran data nilai akhir kompetensi pengetahuan IPA siswa yang digunakan dalam pengujian hipotesis. Uji normalitas sebaran data dilakukan dengan menggunakan uji Chi Kuadrat $\left(X^{2}\right)$ pada taraf signifikansi $5 \%$ dan derajat kebebasan dk $=\mathrm{n}-1$.

Pada kelompok eskperimen berdasarkan nilai $X_{\text {tabel }}^{2}$ pada taraf signifikasi $5 \%$ dan derajat kebebasan $(\mathrm{dk}=6-1=5)$ adalah 11,07 dan hasil analisis $X^{2}{ }_{\text {hitung }}=10,18$ sehingga $X_{\text {hitung }}^{2}<X_{\text {tabel }}^{2}$ maka data berdistribusi normal. Ini berarti sebaran data nilai akhir kompetensi pengetahuan IPA siswa kelompok eksperimen berdistribusi normal. Pada kelompok kontrol berdasarkan nilai $X_{\text {tabel }}^{2}$ pada taraf signifikasi $5 \%$ dan derajat kebebasan $(\mathrm{dk}=6-1=5)$ adalah 11,07 dan hasil analisis $X^{2}{ }_{\text {hitung }}=10,36$ sehingga $X^{2}{ }_{\text {hitung }}<X_{\text {tabel }}^{2}$ maka data berdistribusi normal. Ini berarti sebaran data nilai akhir kompetensi pengetahuan IPA siswa kelompok kontrol berdistribusi normal.

Uji homogenitas varian menggunakan uji $F$. Kriteria pengujian jika $F_{\text {hitung }}<F_{\text {tabel }}$ maka sampel homogen. Pengujian dilakukan pada taraf signifikansi 5\% dengan derajat kebebasan untuk pembilang $n_{1}-1$ $(40-1=39)$ dan derajat kebebasan untuk penyebut $n_{2}-1 \quad(52-1=51)$. Hasil uji homogenitas varian menunjukkan bahwa $F_{\text {hitung }}<F_{\text {tabel }}$ yaitu 1,59 < 1,63. Ini berarti bahwa varian antara kelompok eksperimen dan kelompok kontrol homogen.

Uji hipotesis yang digunakan pada penelitian ini adalah uji beda mean (uji-t) dengan rumus polled varians. Kriteria pengujian adalah $\mathrm{H}_{0}$ ditolak jika $t_{\text {hit }} \geq t_{\text {tabel }}$, dimana $t_{\text {tabel }}$ didapat dari tabel distribusi $\mathrm{t}$ pada taraf signifikansi $(\alpha) 5 \%$ dengan derajat kebebasan $\mathrm{dk}=\left(n_{1}+n_{2}-2\right)$. Hasil perhitungan uji hipotesis disajikan pada tabel berikut.

Tabel 1. Pengujian Hipotesis

\begin{tabular}{ccccccc}
\hline Sampel & Mean & Varian & $\mathrm{N}$ & $\mathrm{t}_{\text {hitung }}$ & $\mathrm{t}_{\text {tabel }}$ & Kesimpulan \\
\hline Kelompok Eksperimen & 76,02 & 63,31 & 52 & 3,71 & 1,98 & $\mathrm{H}_{0}$ ditolak \\
\cline { 1 - 5 } Kelompok Kontrol & 69,43 & 101,20 & 40 & & & \\
\hline
\end{tabular}

\section{Pembahasan}

Setelah menganalisis data post-test rata-rata nilai akhir kompetensi pengetahuan IPA pada kedua kelompok yaitu pada kelompok eksperimen sebesar 76,02 dan pada kelompok kontrol sebesar 69,43. Dari hasil perhitungan diketahui bahwa sebaran data hasil post-test berdistribusi normal dan memiliki varian yang homogen. Dari hasil analisis diperoleh $t_{\text {hitung }}=3,71$. Harga tersebut kemudian dibandingkan dengan harga $t_{\text {tabel }}$ dengan $\mathrm{dk}=52+40-2=90$ dan taraf signifikasi $5 \%$ sehingga diperoleh $\mathrm{t}_{\text {tabel }}=1,98$, Karena $\mathrm{t}_{\text {hitung }}>\mathrm{t}_{\text {tabel }}$, $t_{\text {hitung }}=3,71>t_{\text {tabel }}=1,98$ maka $\mathrm{H}_{0}$ ditolak. Hal ini berarti terdapat perbedaan yang signifikan kompetensi pengetahuan IPA antara kelompok siswa yang dibelajarkan menggunakan model pembelajaran CLIS berbantuan media lingkungan dengan kelompok siswa yang dibelajarkan menggunakan pembelajaran konvensional pada siswa kelas IV SD Gugus Yos Sudarso Kecamatan Denpasar Selatan. Adanya perbedaan yang signifikan menunjukkan bahwa model pembelajaran CLIS berbantuan media lingkungan berpengaruh terhadap kompetensi pengetahuan IPA siswa. Pengaruh antara model pembelajaran CLIS berbantuan media lingkungan dengan pembelajaran konvensional yang hanya dibelajarkan dengan pendekatan saintifik dilihat dari perbedaan hasil analisis statistik deskriptif rata-rata nilai akhir kompetensi pengetahuan siswa kelompok 
eksperimen lebih tinggi yaitu sebesar 76,02 yang termasuk kategori baik dibandingkan dengan rata-rata penguasaan kompetensi pengetahuan siswa kelompok kontrol yaitu sebesar 69,43 yang termasuk kategori cukup.

Perbedaan yang signifikan kompetensi pengetahuan siswa yang menggunakan model pembelajaran CLIS berbantuan media lingkungan disebabkan adanya perbedaan perlakuan pada saat kegiatan pembelajaran berlangsung. Pembelajaran dengan menggunakan model pembelajaran CLIS berbantuan media lingkungan akan memberikan kesempatan kepada siswa untuk berperan aktif dalam kegiatan belajar yang dimulai dari langkah awal yaitu orientasi, pemunculan gagasan, penyusunan ulang gagasan, dan pemantapan gagasan. Adanya variasi model dalam pembelajaran dapat meningkatkan semangat dan minat siswa untuk belajar, yang memengaruhi tingkat konsentrasi siswa dan kematangan pemahaman terhadap sejumlah materi yang diberikan. Pada kelompok kontrol diberikan pembelajaran konvensional yaitu pembelajaran dengan menggunakan pendekatan saintifik. Pembelajaran pada kedua kelompok hampir mirip karena sama-sama menggunakan pendekatan saintifik. Kurikulum 2013 mengharapkan kegiatan pembelajarannya dilaksanakan dengan menggunakan pendekatan saintifik tetapi yang membedakan di kelompok eksperimen menggunakan variasi model dan media pembelajaran yang menyebabkan pembelajaran menyenangkan sehingga mampu membangkitkan semangat dan minat belajar siswa. Sedangkan pada kelompok kontrol hanya menggunakan pendekatan saintifik sehingga hal tersebut dapat mengakibatkan siswa merasa kurang bersemangat dan minat dalam belajar kurang apalagi yang pembelajaran hanya berlangsung di dalam kelas saja.

Adanya beberapa faktor yang menyebabkan perbedaan hasil data post-test pada keduanya mengakibatkan model CLIS berbantuan media lingkungan sangat cocok untuk diterapkan karena siswa lebih banyak aktif dalam menggunakan gagasannya terhadap suatu permasalahan. Hal ini sesuai dengan temuan dari Rahayu (2015: 147) menyatakan bahwa, tujuan dari model pembelajaran CLIS untuk mengungkapkan berbagai gagasan tentang topik yang dibahas dalam pembelajaran, mengungkapkan gagasan serta membandingkan gagasan dengan gagasan siswa lainnya dan mendiskusikannya untuk menyamakan persepsi. Selain itu pembelajaran yang baik harus melihat keefektifan komunikasi sehingga model CLIS dengan berbantuan lingkungan dapat berpengaruh karena lingkungan yang digunakan pada pembelajaran adalah lingkungan yang mereka temui sehari-hari disekolah yang disesuaikan dengan pencapaian indikator pembelajaran. Hal tersebut sesuai dengan temuan dari Erviana (2015) menyebutkan bahwa, memanfaatkan lingkungan sebagai media pembelajaran memiliki beberapa kelebihan antara lain (1) menghemat biaya, (2) memberikan pengalaman yang nyata kepada siswa, (3) pelajaran lebih aplikatif, (4) lebih komunikatif.

Hasil penelitian ini sejalan dengan penelitian yang dilakukan oleh Budiarti (2014) dengan judul "Pengaruh Model Pembelajaran CLIS Terhadap Hasil Belajar IPA Siswa Kelas IV SD di Gugus III Kecamatan Busungbiu". Hasil penelitian Budiarti menunjukkan bahwa, rerata skor hasil belajar pada kelas eksperimen yaitu 14,50 lebih besar dibandingkan rerata skor hasil belajar pada kelas kontrol yaitu 8,32. Penelitian lain juga dilakukan oleh Wardana (2013) yang berjudul "Pengaruh Model Pembelajaran Children Learning In Science (CLIS) terhadap Hasil Belajar IPA Kelas IV SD Gugus VI Kecamatan Sawan”. Hasil penelitian Wardana menunjukkan bahwa, hasil belajar siswa pada kelas eksperimen termasuk pada distribusi juling negatif berarti sebagian besar siswa skor hasil belajar IPA cenderung tinggi sedangkan pada kelas kontrol sebaliknya. Sedangkan untuk penggunaan media lingkungan sejalan dengan penelitian yang dilakukan oleh Aryani (2013) yang berjudul "Pengaruh Pemanfaatan Alam Sekitar Dalam Proses Pembelajaran Terhadap Keterampilan Proses Sains dan Hasil Belajar IPA Kelas V SD Gugus IV Kecamatan Sukasada”. Aryani menyatakan bahwa, pembelajaran dengan pemanfaatan lingkungan sekitar berpengaruh terhadap ketrampilan proses sains siswa dan hasil belajar.

\section{Simpulan dan Saran}

Berdasarkan nilai akhir kompetensi pengetahuan IPA kelompok siswa yang dibelajarkan menggunakan model pembelajaran CLIS berbantuan media lingkungan diperoleh rata-rata sebesar 76,02 berada pada kategori baik sedangkan rata-rata kelompok siswa yang dibelajarkan menggunakan pembelajaran konvensional sebesar 69,43 berada pada kategori cukup.

Berdasarkan hasil analisis dengan uji-t, diketahui $\mathrm{t}_{\text {hitung }}=3,71>\mathrm{t}_{\text {tabel }}=1,98$. Dari perbandingan ini, maka $\mathrm{H}_{0}$ ditolak yang artinya terdapat perbedaan yang signifikan kompetensi pengetahuan IPA antara kelompok siswa yang dibelajarkan menggunakan model pembelajaran CLIS berbantuan media lingkungan dengan kelompok siswa yang dibelajarkan menggunakan pembelajaran konvensional pada siswa kelas IV SD Gugus Yos Sudarso Kecamatan Denpasar Selatan.

Berdasarkan simpulan hasil penelitian maka dapat diajukan saran kepada:

Guru hendaknya tidak hanya menargetkan siswa untuk menguasai kompetensi IPA tanpa memberikan pembelajaran yang bermakna bagi mereka. Para guru disarankan untuk lebih berinovasi dalam menerapkan berbagai model pembelajaran seperti model pembelajaran CLIS berbantuan media lingkungan untuk meningkatkan kompetensi pengetahuan IPA siswa. 
Peneliti lain diharapkan dapat menjadikan penelitian ini sebagai pengalaman langsung sehingga sebagai calon guru Sekolah Dasar dalam mempraktekkan teori-teori yang telah diperoleh di bangku perkuliahan dapat diterapkan secara optimal dan sebagai pembanding dalam melakukan suatu penelitian berikutnya.

Kepala sekolah sebaiknya dapat memakai hasil penelitian ini sebagai bahan pertimbangan dan acuan untuk meningkatkan kualitas pendidikan dalam hal proses pembelajaran khususnya di Sekolah Dasar.

\section{Daftar Pustaka}

Aryani, Luh dkk. 2013. Pengaruh Pemanfaatan Lingkungan Alam Sekitar Dalam Proses Pembelajaran Terhadap Keterampilan Proses Sains dan Hasil Belajar IPA Kelas V SD Gugus IV Kecamatan Sukasada. E-Journal Program Pasca Sarjana Universitas Pendidikan Ganesha, Volume 3.

Budiarti, Luh Putu Yudha dkk. 2014. Pengaruh Model Pembelajaran CLIS Terhadap Hasil Belajar IPA Siswa Kelas IV SD di Gugus III Kecamatan Busungbiu. Jurnal Mimbar PGSD Universitas Pendidikan Ganesha, Volume 2 nomor 1.

Dantes, Nyoman. 2012. Metode Penelitian.Yogyakarta: ANDI.

Emda, Amna. 2011. Pemanfaatan Media Dalam Pembelajaran Biologi di Sekolah. Jurnal Ilmiah DIDAKTIKA, Volume 12 nomor 1.

Erviana, Lina. 2015. Pemanfaatan Media Pembelajaran Berbasis Lingkungan Sebagai Sarana Praktikum IPA Untuk Meningkatkan Pemahaman Konsep Siswa di SMP-IT AR Rahmah Pacitan. Jurnal Dinamika Pendidikan Dasar, Volume 7 nomor 2.

Kosasih, E. 2014. Strategi Belajar dan Pembelajaran Implementasi Kurikulum 2013. Bandung: Yrama Widya. Kurniasih, Imas dan Berlin Sani. 2014. Sukses Mengimplementasikan Kurikulum 2013. Surabaya: Kata Pena. Rahayu, Esti Setya. 2015. Aplikasi Model CLIS (Children's Learning In Science) Untuk Meningkatkan Kreativitas Belajar Kimia Siswa Kelas X MAN Tulungangung 1 Melalui Pembuatan Briket Sampah Organik. Jurnal Review Pendidikan Islam, Volume 01 nomor 02.

Sagala, Syaiful. 2013. Konsep dan Makna Pembelajaran. Bandung: Alfabeta.

Sani, Ridwan Abdullah. 2014. Pembelajaran Saintifik untuk Implementasi Kurikulum 2013. Jakarta: PT Bumi Aksara.

Samatowa, Usman. 2016. Pembelajaran IPA di Sekolah Dasar, Cetakan Ke 3. Jakarta: PT Indeks.

Setiawan, Denny, dkk. 2009. Komputer dan Media Pembelajaran. Jakarta: Universitas Terbuka.

Sinambela, Pardomuan Nauli Josip Mario. 2013. Kurikulum 2013 dan Implementasinya Dalam Pembelajaran. Jurnal Generasi Kampus volume 6 nomor 2 tahun 2013.

Sukmadinata, Nana Syaodih. 2012. Metode Penelitian Pendidikan. Bandung: PT Remaja Rosdakarya.

Susanto, Ahmad. 2013. Teori Belajar dan Pembelajaran di Sekolah Dasar. Jakarta: Kencana.

Uno, Hamzah B dan Nurdin Mohamad. 2012. Belajar dengan Pendekatan PAILKEM. Jakarta: Bumi Aksara.

Wardana, Wayan Adi dkk. 2013. Pengaruh Model Pembelajaran Children Learning In Science (CLIS) terhadap Hasil Belajar IPA Kelas IV SD Gugus VI Kecamatan Sawan. Jurnal Mimbar PGSD Universitas Pendidikan Ganesha, Volume 2 nomor 1.

Wisudawati, Asih Widi dan Eka Sulistyowati. 2014. Metodelogi Pembelajaran IPA. Jakarta: Bumi Aksara. 